\title{
Microbiological Quality of Salads Served along with Street Foods of Hyderabad, India
}

\author{
Alekhya Sabbithi, ${ }^{1}$ R. Naveen Kumar, ${ }^{1}$ L. Kashinath, ${ }^{1}$ V. Bhaskar, ${ }^{2}$ and V. Sudershan Rao \\ ${ }^{1}$ Food and Drug Toxicology Research Center, National Institute of Nutrition, Indian Council of Medical Research (ICMR), \\ Jamai Osmania, Tarnaka, Hyderabad 500007, India \\ ${ }^{2}$ Statistical Division, National Institute of Nutrition, Indian Council of Medical Research (ICMR), Hyderabad, India
}

Correspondence should be addressed to V. Sudershan Rao; vemulasr@yahoo.com

Received 27 December 2013; Revised 28 April 2014; Accepted 28 April 2014; Published 14 May 2014

Academic Editor: Todd R. Callaway

\begin{abstract}
Copyright (C) 2014 Alekhya Sabbithi et al. This is an open access article distributed under the Creative Commons Attribution License, which permits unrestricted use, distribution, and reproduction in any medium, provided the original work is properly cited.
\end{abstract}

A study has been done to analyse the microbiological quality of salads served along with street foods of Hyderabad. A total of 163 salad samples, 53 of carrot and 110 of onion samples, were collected from four different zones of Hyderabad. About $74 \%$ and $56 \%$ had Staphylococcus aureus in carrots and onions, respectively. Fifty-eight percent of carrots and forty-five percent of onions samples contained Salmonella, 68\% of carrots and 24\% of onions had Yersinia. HACCP study was carried out with 6 street food vendors to identify the source of Salmonella contamination in salads. Food handlers were found to be responsible for Salmonella contamination in salads. The present study revealed the potential hazards of street vended salad vegetables, considering the handling practice usually carried out by vendors. Ninety-eight percent of the vendors did not wash the vegetables before processing and serving while about $56.6 \%$ of the vendors did not peel the vegetables. Majority of street vendors' nails were uncut. A significant difference $(P<0.01)$ was observed in Yersinia spp. and Salmonella spp. in wet-dirty chopping board when compared to clean-dry chopping board. A significant difference $(P<0.05)$ of Staphylococcus spp. was observed when the status of cleaning cloth was neat/untidy.

\section{Introduction}

Street vended food (SVF) includes food and beverages that are prepared and sold outdoors or in public spaces by street merchants for consumption at the location or later without further preparation [1]. Quality and safety are two common concerns with regard to street foods. Poor hygiene and sanitation practices are one of the major bottlenecks in street food vending [2].

Salad can be defined as a food made primarily of mixture of raw vegetables and/or fruits [3]. The possibility of foodborne diseases is more when salad vegetables are consumed without any heat treatment, sometimes without washing and peeling [4]. Water used for rinsing the vegetables and sprinkling to keep them fresh is also a source of contamination [5]. Fresh vegetables and fruits become contaminated with microorganisms during production, harvest, packing, and distribution [6].
Ready-to-eat fruit and vegetables requiring minimal or no further processing prior to consumption have been implicated as vehicles for transmission of infectious microorganisms of foodborne outbreaks related to gastrointestinal illness associated with fruit and vegetables [7]. In this context the present study was undertaken to analyse the microbiological quality of salads served along with street foods of Hyderabad city.

\section{Materials and Methods}

2.1. Study Area. The Study was carried out in Hyderabad which is the capital of Andhra Pradesh, India. The twin cities of Hyderabad and Secunderabad come under ambit of a single municipal unit, the Greater Hyderabad Municipal Corporation. For administrative purpose Greater Hyderabad Municipal Corporation was divided into many zones. Random sampling procedure was adopted to select four 
zones (Alwal: east zone, Yousufguda: west zone, Old City: south zone, and Secunderabad: north zone). The sample required for the study was obtained using proportionate representation according to size.

2.2. Questionnaire. Personal interview of the street vendor was taken and flow chart was prepared from which critical control points of contamination were examined.

Data on salad preparation, handling, and storage practices was collected using structured questionnaire that had both observational and responsive questions. Equipment used for the preparation of salad, source of water for both utensil cleaning and vegetables, utensil cleaning methods, and hand washing were considered. Salad preparation, handling practices, storage of leftover salad, storage length, and salad storage practices were observed and noted. Information on status of the premises, storage conditions for salad before cooking, cutting and chopping place, status of the serving plate, peeling and cleaning of vegetables, cleanliness of the cloth and clothing used, provision for waste disposal, presence of rodent droppings in the outlet, and exposure to insects was gathered.

\subsection{Hazard Analysis Critical Control Point (HACCP).} HACCP was carried outin order to understand the critical points for the contamination; information on source of purchasing of salad vegetables, their transportation, storage, and further processing before consumption was obtained through personal interviews of the street food vendors $(n=53)$. Based on this information the process flow diagram was constructed. HACCP is a system which identifies, evaluates, and controls hazards which are significant for food safety. The hazard analysis includes observing salad preparation and practices to identify the sources and modes of contamination. Preparation of process flow diagram is a prerequisite for carrying out HACCP.

Samples of hand washings, knife swab, and chopping board swab were collected from six street food vendors $(n=$ 6 ) and examined for presence of food pathogens.

\subsection{Sample Collection and Processing. A total of 163 samples} were collected from four different zones of Hyderabad. Samples were transported to the laboratory in aseptic condition. The polythene zip lock bags with salad samples were kept in an ice box maintained at 6-10 degree centigrade and processed within 2-4 hrs. Twenty-five grams of each salad sample was weighed and transferred to $225 \mathrm{~mL}$ of sterile buffered peptone water. The diluents of buffered peptone water were then inoculated onto the respective media.

2.5. Identification and Enumeration. Identification and enumeration of foodborne pathogens (S. aureus, Salmonella spp., and Yersinia enterocolitica) were performed as described by standard methods of bacteriological analytical manual. After thoroughly mixing the food sample ( $25 \mathrm{~g}$ ) in buffered peptone water $(225 \mathrm{~mL})$ by $1: 10$ dilution, the diluents were inoculated onto their respective selective media such as MSA (mannitol salt agar) for Staphylococcus aureus with small round pale
TABLE 1: Incidence of foodborne pathogens in salads given along with street foods in Hyderabad.

\begin{tabular}{lcc}
\hline Pathogen & Carrot $(n=53)$ & Onion $(n=110)$ \\
\hline Staphylococcus & $39(73.6 \%)$ & $62(56.4 \%)$ \\
Salmonella & $31(58.5 \%)$ & $50(45.5 \%)$ \\
Yersinia & $36(67.9 \%)$ & $26(23.6 \%)$ \\
\hline
\end{tabular}

colored colonies, XLD (xylose lysine deoxycholate agar) for Salmonella spp. with red colored colonies with black centre, and YSA (Yersinia selective agar) for Yersinia spp.with transparent colonies with pink centre. After inoculation the plates were incubated for $24 \mathrm{hrs}$ at $37^{\circ} \mathrm{C}$ in incubator. Morphological tests such as grams staining and motility tests (coagulase test for S. aureus) were conducted followed by biochemical tests using $\mathrm{Hi}$ assorted biochemical test kit (A combination of 12 tests for identification of gram-negative rods. Kits contain sterile media for citrate utilization, lysine utilization and ornithine utilization, urease detection phenylalanine deamination (TDA), nitrate reduction, $\mathrm{H}_{2} \mathrm{~S}$ production test, and 5 different carbohydrates for utilization test: glucose, adonitol, lactose, arabinose, and sorbitol) followed by latex agglutination test kit supplied by HiMedia.

2.6. Statistical Analysis. The analysis was carried out by descriptive analysis (mean, minimum, and maximum) for each category of the group. Difference between the groups was tested by nonparametric Kruskal-Wallis ANOVA considering the heterogeneity of variance. Individual pair difference was tested by Mann-Whitney $U$ test (SPSS-14.8 windows version was used).

\section{Results}

Microbiological analysis of salads indicated that both onion and carrot were contaminated with three pathogens. Salmonella was present in 58\% in carrots and $45 \%$ of onion samples. Compared to onions, carrots harboured higher percentage of contamination (Table 1). Among the carrot samples procured from four zones of Hyderabad, Old City, that is, south zone, has shown high levels of contamination compared to other zones. The mean concentration ranges of Staphylococcus, Salmonella, and Yersinia in carrot and onion are shown (Table 2).

Seventy-six percent of onion samples from east zone had Staphylococcus which is high when compared to other zones. Salmonella was not detected in onion samples of east zone. In Old City, that is, south zone, $76 \%$ of onion samples had Salmonella which is high when compared to other zones (Figure 2). Samples of carrots have high levels of contamination when compared to onions.

Process flow diagram of onion and carrot indicated that, after peeling the outer skin of the onions, they were directly cut into small pieces and served without washing them. It was observed that the peeling which is very important step in processing of carrots was not done; they were directly grated and served (Figure 1). HACCP study on contamination 
TABLE 2: Mean concentration ranges of Staphylococcus, Salmonella, and Yersinia in salad samples.

\begin{tabular}{|c|c|c|c|c|}
\hline Pathogens & Carrot $(\min -\max )$ & Mean & Onion (min-max) & Mean \\
\hline Staphylococcus & $2.0-5.2\left(10^{2}-10^{5}\right)$ & 4 & $2.0-5.0\left(10^{2}-10^{5}\right)$ & 3.2 \\
\hline Salmonella & $3.0-5.4\left(10^{3}-10^{5}\right)$ & 4.4 & $2.0-5.4\left(10^{2}-10^{5}\right)$ & 3.9 \\
\hline Yersinia & $3.3-5.4\left(10^{3}-10^{5}\right)$ & 4.5 & $2.9-4.8\left(10^{2}-10^{5}\right)$ & 3.9 \\
\hline
\end{tabular}

${ }^{*}$ Range of microbial counts $(\log 10 \mathrm{cfu} / \mathrm{g})$.

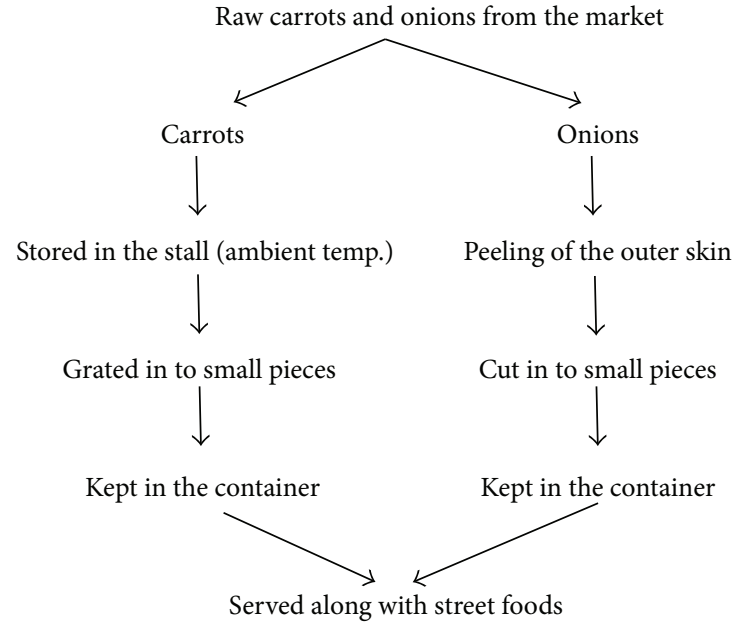

Figure 1: Process flow diagram for onions.

of Salmonella in salads indicated that food handlers were responsible for Salmonella contamination (Table 4).

Most of the vendors got vegetables from whole sale market and $56 \%$ of the vendors stored them in their house and $44 \%$ of them stored it in the stall itself. About $98 \%$ of the vendors did not wash the vegetables before processing and $56 \%$ of the vendors did not peel carrots before cutting. Ninety-two percent of the vendors used knife to cut the vegetables out of which $77 \%$ of the knives were wet and dirty and $88 \%$ of the vendors did not wash knife frequently. About $54 \%$ of the vendors kept salads in open air without covering them properly. Ninety percent of them used wooden board for cutting and chopping vegetables. About $90 \%$ of the vendors' cleaning cloths were untidy and none of them wore gloves before serving salads. There were about $60 \%$ of the vendors whose nails were uncut. About $64 \%$ of the stalls are adjacent to road (Table 3 ).

\section{Discussion}

The study demonstrated that salads served along with popularly sold street foods are contaminated with one or many pathogens. A recent foodborne disease outbreak during 2011 in Europe and Germany was mainly due to contamination of salads such as cucumber, tomatoes, and lettuces by harmful strain of E. coli O104:H4 [8]. Salmonella and Staphylococcus aureus were the other major pathogens found in salads. A study conducted in Dehradun, India, has shown that different types of salads such as carrot, radish, tomato, coriander leaves, turnip, onion, cucumber, and beetroot were

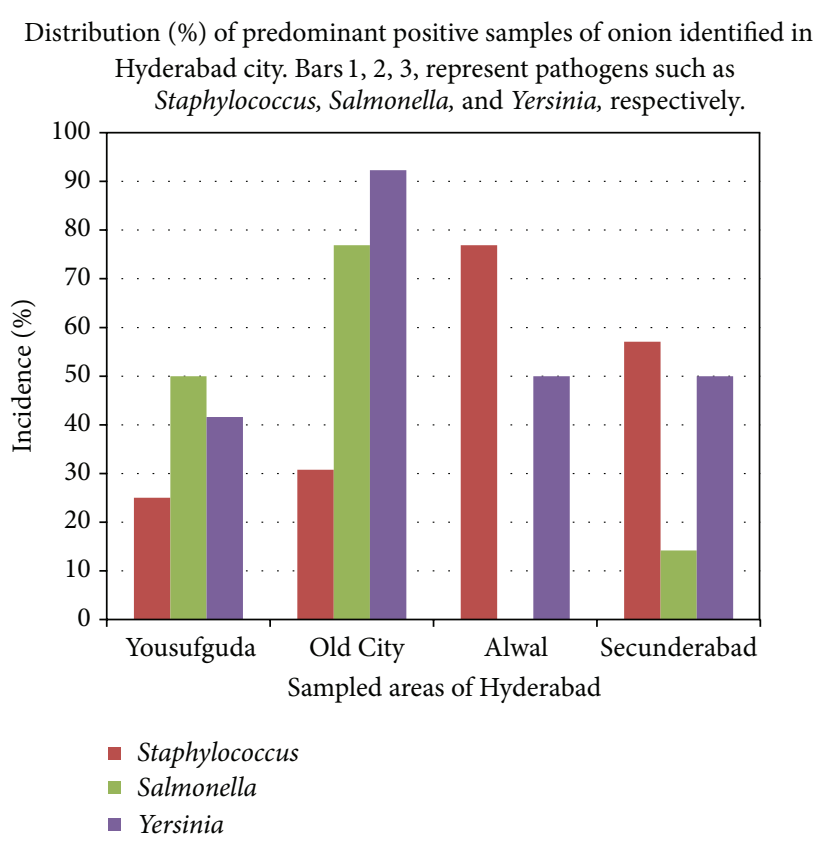

FIGURE 2: Prevalence of foodborne pathogens in onion samples of Hyderabad city.

contaminated with Salmonella (32.28\%), E. coli (33.14\%), S. aureus (50.57\%), and $P$. aeruginosa (60.85\%) [9].

In this present study carrot and onion were chosen because they are the most commonly served salads in street foods of Hyderabad. About $74 \%$ and $56 \%$ tested positive for Staphylococcus in carrots and onions, respectively. About $58 \%$ of carrots and $45 \%$ of onions contained Salmonella and $68 \%$ of carrots and $24 \%$ of onions had Yersinia. Type of pathogens reported in salads, specifically with carrot, was E. coli O157:H7, Salmonella spp., and L. monocytogenes and for onions was E. coli and Salmonella typhimurium [10]. The presence of microbes in salads can be linked to a number of factors such as improper handling and processing, use of contaminated water during washing and dilution, crosscontamination from rotten vegetables, or the use of dirty processing utensils like knife and trays $[11,12]$. The present study indicated that the bacterial load of carrots was high when compared to onions because carrots were not peeled. Peeling as expected reduces the bacterial load; a study done by Ankitha et al. indicated that a reduction of about $40 \%$ of bacterial load was observed in peeled carrot [3].

The contamination by Staphylococcus aureus may be due to its carriage in nasal passages of food handlers or infected workers [13]. The contamination of Salmonella spp. 
TABLE 3: Salad handling practices and preparation and storage practices of 53 street food venders in Hyderabad city.

\begin{tabular}{cc}
\hline Practices & Frequency of responses $(n=53)$ \\
$\%$
\end{tabular}

Vegetables from
(a) Market
49 (92.5)

(b) Shop

$4(7.5)$

Vegetables brought in
(a) Polythene bag
23 (43.4)
(b) Gunny bags
$30(56.6)$

Frequency
(a) Once in a day
(b) Once in 2 days
(c) Once in 5 days
(d) Once in a week

8 (15.1)

15 (28.3)

$16(30.2)$

$14(26.4)$

Storage
(a) House
$30(56.6)$
(b) Stall
$23(43.4)$

Storage before cutting
(a) Table
(b) Bowl
(c) Bucket
(d) Refrigerator
(e) Others

10 (18.9)

$11(20.8)$

12 (22.6)

10 (18.9)

10 (18.9)

Wash vegetables
(a) Yes
$1(1.9)^{*}$
(b) No
$52(98.1)$

Peeling vegetables
(a) Yes
23 (43.4)
(b) No
$30(56.6)$

Peeled with
(a) Peeler
1 (1.9)
(b) Knife
$22(41.5)$
(c) Not peeled
$30(56.6)$

Cutting vegetable
(a) Knife
$49(92.5)$
(b) Vegetable cutter $3(5.7)$
(c) Grater
$1(1.9)$

Status of knife
(a) Clean-dry
15 (28.3)
(b) Wet-dirty
$38(71.7)$

Storage after cutting
(a) Open place
$29(54.7)$
(b) Container
$24(45.3)$

Selling of non-veg. food
(a) Yes
$6(11.3)^{\sim}$
(b) No
47 (88.6)

Frequent washing of knife
(a) Yes
$6(11.3)$
(b) No
$47(88.7)$

Cutting and chopping place
(a) Wooden
$48(90.6)$
(b) Stainless table
$5(9.4)$

TABle 3: Continued.

\begin{tabular}{lc}
\hline Practices & $\begin{array}{c}\text { Frequency of responses }(n=53) \\
\%\end{array}$ \\
\hline Status of cleaning cloth & $5(9.4)$ \\
(a) Neat & $48(90.6)$ \\
(b) Dirty & \\
Does vendor wear gloves? & $53(100)$ \\
(a) No & \\
Frequent washing of hands & $3(5.7)$ \\
(a) Yes & $50(94.3)$ \\
(b) No & \\
Status of his nails & $21(39.6)$ \\
(a) Neat & $32(60.4)$ \\
(b) Dirty & \\
Wounds & $6(11.3)$ \\
(a) Cut & $1(1.9)$ \\
(b) Wound & $46(86.8)$ \\
(c) No wound & \\
Status of nails & $21(39.7)$ \\
(a) Cut & $32(60.3)$ \\
(b) Uncut & \\
Neatly combed & $16(30.2)$ \\
(a) Yes & $37(69.8)$ \\
(b) No &
\end{tabular}

Uniform
(a) Neat
$12(22.6)$
(b) Dirty
$41(77.4)$

Status of premises
(a) Near to the water drain
(b) Adjacent to road
$34(64.2)$
(c) Near public toilet
$3(5.7)$
(d) Near municipal garbage
$4(7.5)$
(e) Others
$3(5.7)$

Waste disposal
(a) Garbage bin
$40(75.5)$
(b) Plastic bag
$12(22.6)$
(c) Outside

Stray dogs and cats in vicinity

(a) Yes

$53(100)$

Rodent droppings
(a) Yes
$31(58.5)$
(b) No
$22(41.5)$

Insect exposure
(a) Yes
$51(96.2)$
(b) No
$2(3.8)$

${ }^{*}$ Washing is done with still water. ${ }^{\sim}$ Use same knife to cut vegetables and meat.

in vegetables was due to washing of vegetables with contaminated water and handling of vegetables by infected workers, vendors, and consumers in the market place which helps spread pathogenic microorganisms. HACCP study revealed that raw vegetables (carrot and onion) themselves carried pathogens and since they were not washed they continued to be present at the time of consumption. Hand washings also contained Salmonella which indicate that even food handlers contaminate the salads. 
TABLE 4: HACCP analysis of Salmonella (cfu/g) contamination in salads.

\begin{tabular}{lcccc}
\hline & Salad sample & Hand wash & Knife swab & Chopping board swab \\
\hline Vendor 1 & $\mathrm{ND}$ & $1 \times 10^{3}$ & $\mathrm{ND}$ & $\mathrm{ND}$ \\
Vendor 2 & $7 \times 10^{4}$ & $12 \times 10^{4}$ & $\mathrm{ND}$ & $\mathrm{ND}$ \\
Vendor 3 & $3 \times 10^{5}$ & $6 \times 10^{3}$ & $18 \times 10^{3}$ & $5 \times 10^{4}$ \\
Vendor 4 & $\mathrm{ND}$ & $6 \times 10^{3}$ & $\mathrm{ND}$ & $\mathrm{ND}$ \\
Vendor 5 & $3 \times 10^{5}$ & $\mathrm{ND}$ & $4 \times 10^{3}$ & $3 \times 10^{5}$ \\
Vendor 6 & $\mathrm{ND}$ & $1 \times 10^{4}$ & $\mathrm{ND}$ & $1 \times 10^{3}$ \\
\hline
\end{tabular}

ND: not detected.

Previous studies have demonstrated that Salmonella cross-contamination occurs frequently through the use of contaminated vegetables that are improperly cleaned and undisinfected [14-16]. The serving stage is a critical point in the street food vending. Poor personal hygiene often facilitates transmission of 60 pathogens via food to humans [17]. Most of the vendors were not using hand gloves while preparing and serving street food. Vendors were carriers of a variety of bacterial enteropathogens, including $S$. typhimurium [18]. Similarly Escherichia coli was detected in hand washings of high income and low income mothers in India at levels of $7.0 \pm 4.2 \log 10 \mathrm{cfu} / \mathrm{mL}$ and $9.0 \pm$ $5.7 \log 10 \mathrm{cfu} / \mathrm{mL}$, respectively [18]. A significant difference $(P<0.01)$ was observed in load of Salmonella spp. in wet, dirty chopping board when compared to the load of Salmonella in clean and dry chopping board. Similarly the load of Yersinia spp. was high in wet, dirty chopping board when compared to the load of Yersinia spp. in clean and dry chopping board. A significant difference $(P<0.05)$ was observed in the load of Staphylococcus spp. in cleaning cloth which was dirty used by the vendor when compared to the load of Staphylococcus in neat cloth used by the vendor. The pathogenic bacteria population was significantly higher in south circle because demographically this circle belongs to the old part of the city wherein the density of the population is high and most of the population was inhabited by lower income group which may be one of the factors contributing to poor hygienic practices.

\section{Conclusions}

The present study revealed that the potential hazard of street vended salad vegetables may be due to handling practices of vendors and poor hygienic conditions in which they are sold. Salads can be a potential source of Salmonella infection among the consumers. A simple thorough washing of vegetables with safe running water before further processing reduces the risk of microbiological hazards. There is a need to provide basic training on food hygiene to food vendors to ensure food safety and also create consumer awareness of consuming improperly processed salads as one of the possible sources of microbial hazards.

\section{Conflict of Interests}

The authors declare that there is no conflict of interests regarding the publication of this paper.

\section{Acknowledgment}

The authors acknowledge the encouragement given to them during the course of study by the Director, National Institute of Nutrition, Indian Council of Medical Research (ICMR), Hyderabad, India.

\section{References}

[1] K. Cho, S. Park, and N. Joo, "Study on a model of street vended food choices by Korean high school students," Nutrition Research and Practice, vol. 5, no. 5, pp. 481-488, 2011.

[2] A. M. Omemu and S. T. Aderoju, "Food safety knowledge and practices of street food vendors in the city of Abeokuta, Nigeria," Food Control, vol. 19, no. 4, pp. 396-402, 2008.

[3] R. Ankita, "Bacterial load on street Vended Salads in Jaipur City, India," Internet Journal of Food Safety, vol. 12, pp. 136-139, 2010.

[4] D. H. Tambekar and R. H. Mundhada, "Bacteriological quality of salad vegetables sold in Amravati City (India)," Journal of Biological Sciences, vol. 6, no. 1, pp. 28-30, 2006.

[5] P. Mensah, D. Yeboah-Manu, K. Owusu-Darko, and A. Ablordey, "Street foods in Accra, Ghana: how safe are they?" Bulletin of the World Health Organization, vol. 80, no. 7, pp. 546554, 2002.

[6] S. Udo, I. Andy, A. Umo, and M. Ekpo, "Potential human pathogens (Bacteria) and their Antibiogram in Readt to eat salads sold in Calabar, South-South, Nigeria," The Internet Journal of Tropical Medicine, vol. 5, no. 2, p. 1, 2009.

[7] M. Abadias, J. Usall, M. Anguera, C. Solsona, and I. Viñas, "Microbiological quality of fresh, minimally-processed fruit and vegetables, and sprouts from retail establishments," International Journal of Food Microbiology, vol. 123, no. 1-2, pp. 121-129, 2008.

[8] WHO, "EHEC outbreak: 9 European countries report cases of haemolytic uraemic syndrome and enterohaemorrhagic E. coli infections," http://www.euro.who.int/en/health-topics/ communicable-diseases/pages/news/news/2011/05/ehecoutbreak-9-european-countries-report-cases-of-haemolyticuraemic-syndrome-and-enterohaemorrhagic-e.-coliinfections.

[9] K. Dheeraj, V. Ram Naresh, and U. V. S. Teotia, "Enterobacter and other Pathogens in Salads and Spouts," 2012, http:// www.onlineijra.com/catogery/.../Enterobacteria_and_other_ pathogens.pdf.

[10] S. R. Cruz, Y. Luo, R. J. Gonzalez, Y. Tao, and G. A. González, "Acidified sodium chlorite as an alternative to chlorine to control microbial growth on shredded carrots while maintaining quality," Journal of the Science of Food and Agriculture, vol. 86, no. 12, pp. 1887-1893, 2006. 
[11] F. L. Bryan, P. Teufel, S. Riaz, S. Roohi, F. Qadar, and Z. U. R. Malik, "Hazards and critical control points of street- vended chat, a regionally popular food in Pakistan," Journal of Food Protection, vol. 55, pp. 708-713, 1992.

[12] K. Khalil, G.-B. Lindblom, K. Mazhar, and B. Kaijser, "Flies and water as reservoirs for bacterial enteropathogens in urban and rural areas in and around Lahore, Pakistan," Epidemiology and Infection, vol. 113, no. 3, pp. 435-444, 1994.

[13] L. R. Beuchat, "Food safety issues. surface decontamination of fruits and vegetables eaten raw: a review," Tech. Rep. WHO/FSF/FOS/98.2, Food Safety Unit, World Health Organization (WHO), Geneva, Switzerland, 1998.

[14] F. M. Mosupye and A. von Holy, "Microbiological quality and safety of ready-to-eat street- vended foods in Johannesburg, South Africa," Journal of Food Protection, vol. 62, no. 11, pp. 1278-1284, 1999.

[15] S. O’Brien, R. T. Mitchell, I. Gillespie, and G. K. Adak, "The microbiological status of ready-to-eat fruit and vegetables," 2001, http://onlinelibrary.wiley.com/doi/10.1046/j.1472765X.2001.01026.x/pdf.

[16] T. J. Humphrey, K. W. Martin, J. Slader, and K. Durham, "Campylobacter spp. in the kitchen: spread and persistence," Symposium Series-Society for Applied Microbiology, vol. 30, pp. 115-120, 2001.

[17] H. D. Mepba, S. C. Achinewhu, S. N. Aso, and C. K. Wachukwu, "Microbiological quality of selected street foods in Port Harcourt, Nigeria," Journal of Food Safety, vol. 27, no. 2, pp. 208-218, 2007.

[18] R. Mathur and V. Reddy, "Bacterial contamination of infant foods," Indian Journal of Medical Research, vol. 77, no. 3, pp. 342346, 1983. 

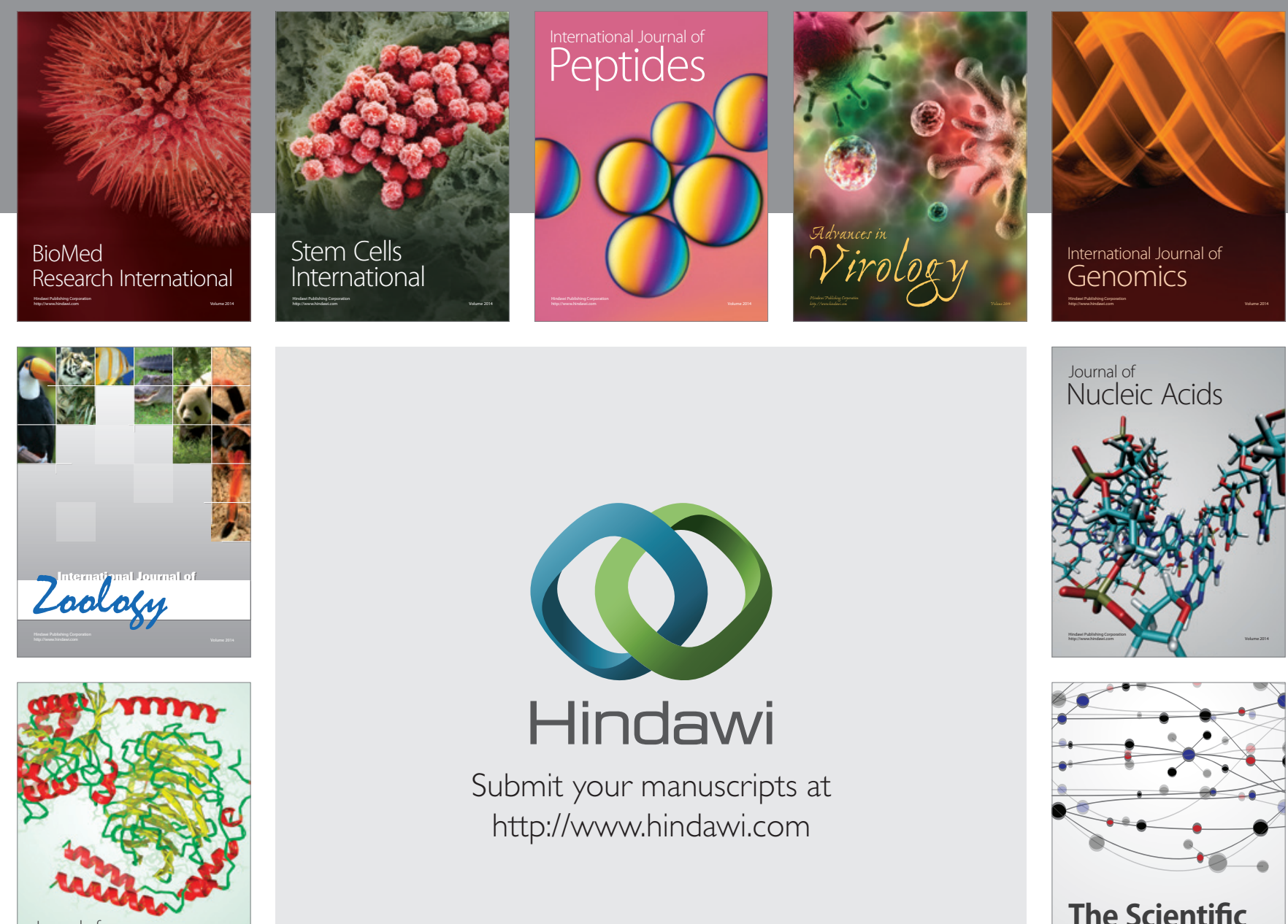

Submit your manuscripts at

http://www.hindawi.com

Journal of
Signal Transduction
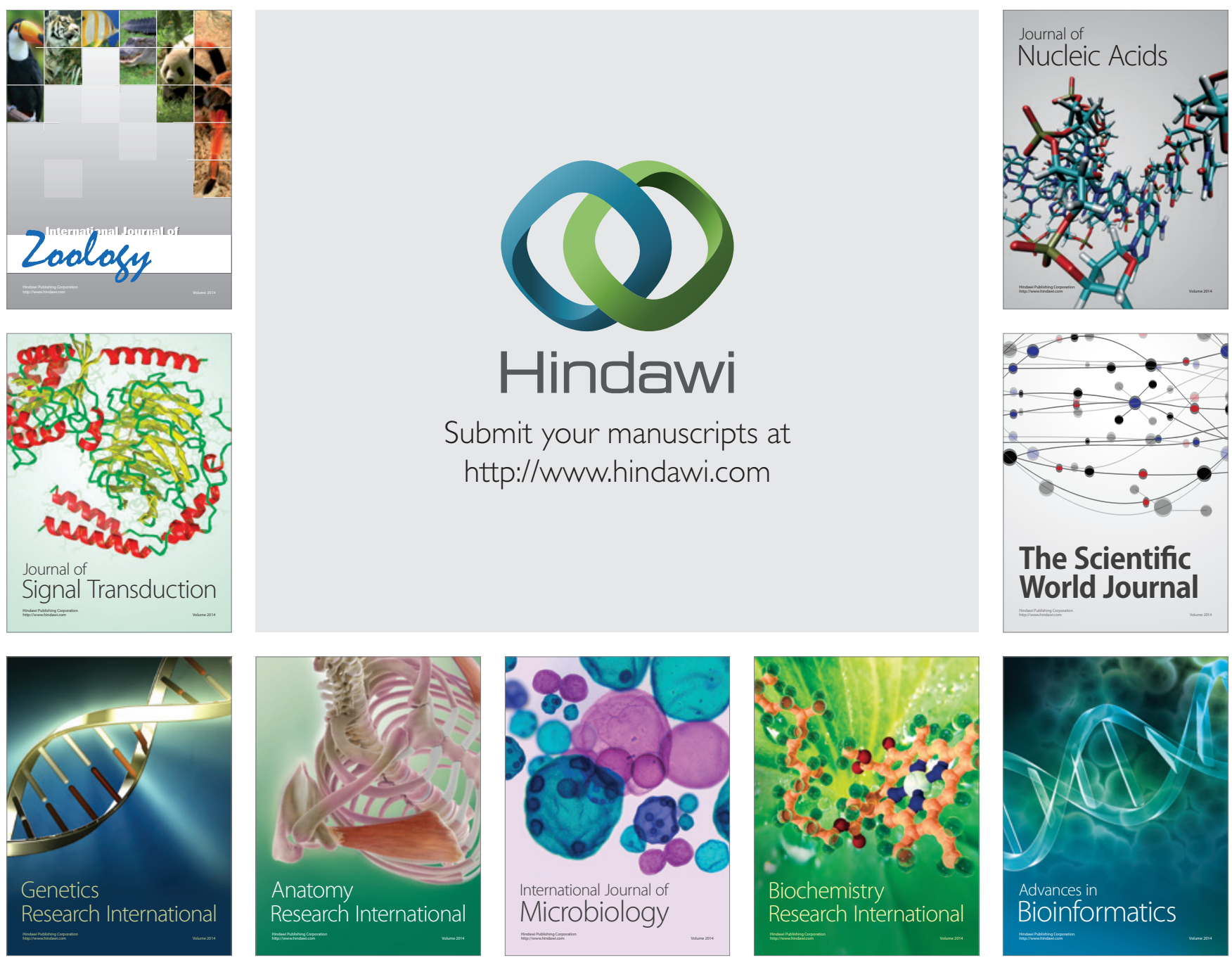

The Scientific World Journal
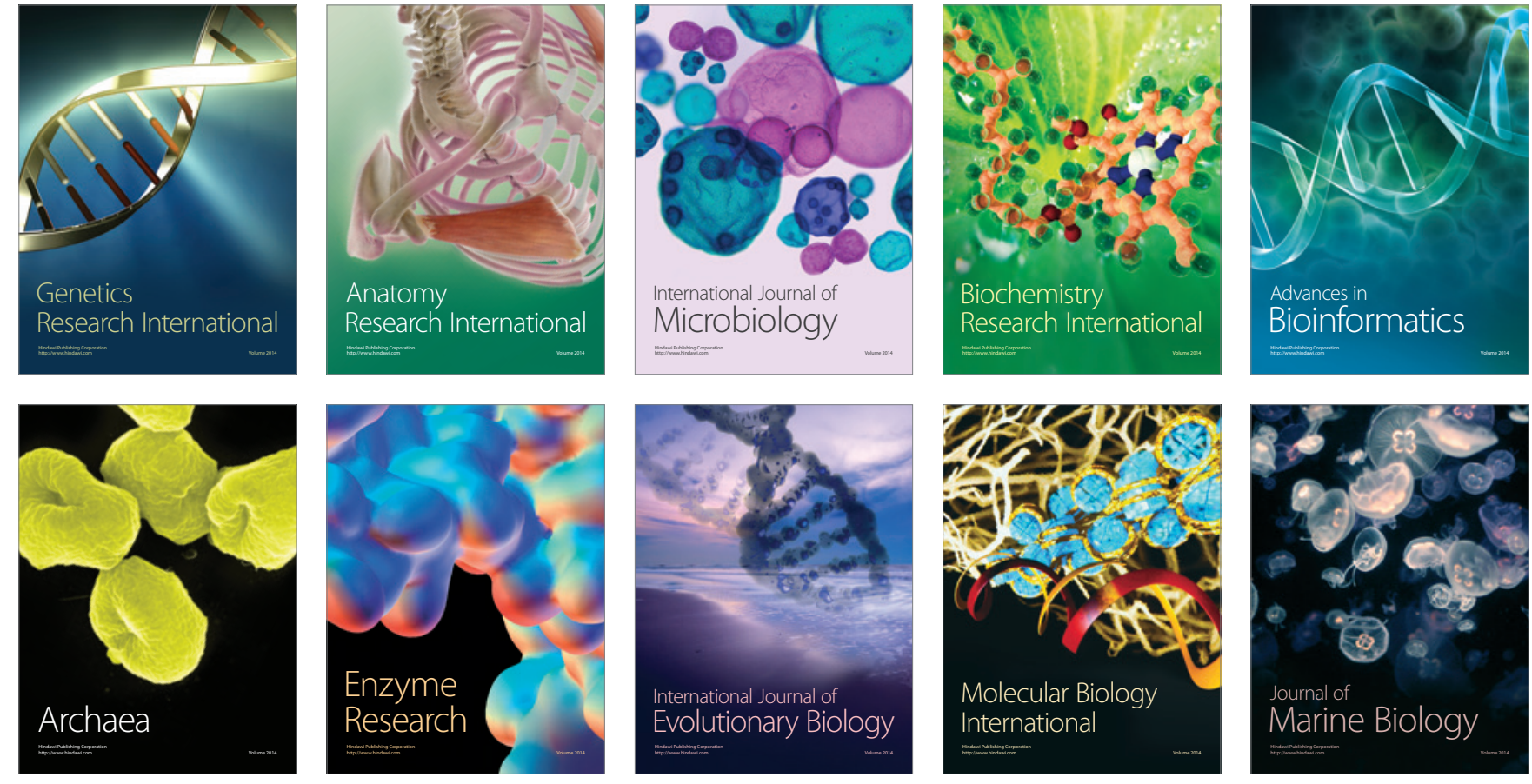